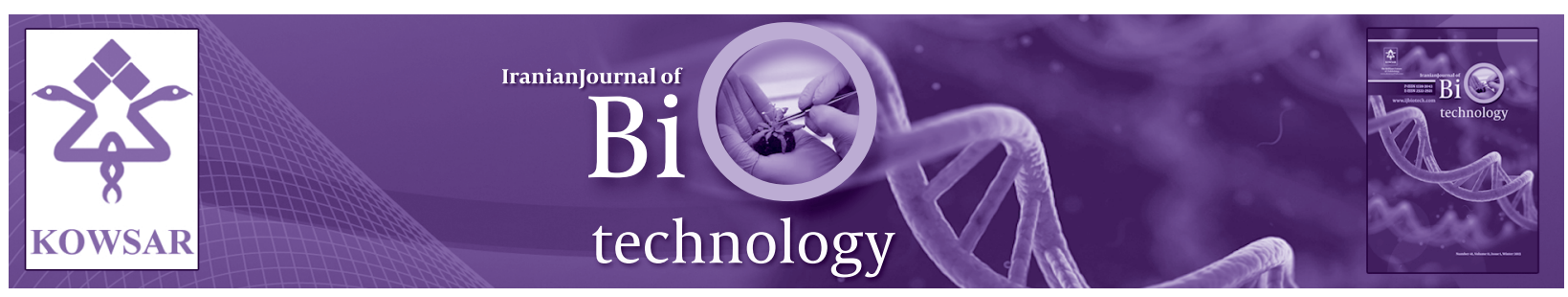

\title{
Preparation of Antibody Against Immunodominant Membrane Protein (IMP) of Candidatus Phytoplasma aurantifolia
}

\author{
Fatemeh Shahryari ${ }^{1}$, Masoud Shams-Bakhsh ${ }^{{ }^{*}}$, Mohammad Reza Safarnejad ${ }^{2,3}$, Naser Sa- \\ faie $^{1}$, Saeed Ataei Kachoiee ${ }^{4}$ \\ ${ }^{1}$ Department of Plant Pathology, Faculty of Agriculture, Tarbiat Modares University, Tehran, IR Iran \\ 2 Department of Microbial Biotechnology and Biosafety, Agricultural Biotechnology Research Institute of Iran, Karaj, IR Iran \\ ${ }^{3}$ Department of Plant Viruses, Iranian Research Institute of Plant Protection, Tehran, IR Iran \\ ${ }^{4}$ Razi Vaccine and Serum Research Institute, Tehran, IR Iran
}

\section{A R T I C L E I N F O}

Article type:

Research Article

Article history:

Received:10 Jun 2011

Revised: 11 Oct 2012

Accepted: 26 Nov 2012

\section{Keywords:}

DIBA

ELISA

Lime

Recombinant Protein

\begin{abstract}
A B S T R A C T
Background: The witches' broom disease of lime caused by Candidatus Phytoplasma aurantifolia, is the most devastating disease of acidian lime in the southern parts of Iran. objectives: At present, no efficient method has been developed for controlling the disease, therefore quarantine approaches such as early detection and subsequent eradication of infected trees is very important. Toward this aim, developing a reliable and sensitive detection method would be the first step to prevent transportation of infected plant materials to other places.

Materials and Methods: In this study, Immunodominant membrane protein (IMP) of the pathogen was selected as a target for detection and preparation of polyclonal antibody. The IMP is the major protein present on the surface of phytoplasma cells. For this purpose, the DNA region encoding IMP gene was isolated and cloned into pET28a bacterial expression vector. The recombinant protein was expressed in a large scale in Escherichia coli. Purification was performed under native conditions and the purity and integrity of produced recombinant protein were confirmed by western immuno blot analysis using anti His-tag and anti-IMP polyclonal antibodies. The purified recombinant IMP was used for immunization of rabbit. Purification of immunoglobulin was performed by affinity chromatography using protein A column. The purified immunoglobulin was conjugated with the alkaline phosphatase enzyme.

Results: The purified antibodies and conjugates were applied for efficient detection of infected plants in double antibody sandwich enzyme-linked immunosorbent assay (DAS-ELISA) and dot immunosorbent assay (DIBA).

Conclusions: These antibodies were proven to be very powerful tools to detect the Candidatus Phytoplasma aurantifolia in plants. Published by Kowsar Corp, 2013. cc 3.0.
\end{abstract}

- Implication for health policy/practice/research/medical education:

This study has implication on plant pathology research.

- Please cite this paper as:

Shahryari F, Shams-Bakhsh M, Safarnejad MR, Safaie N, Ataei Kachoiee S. Preparation of Antibody Immunodominant Membrane Protein (IMP) of Candidatus Phytoplasma aurantifolia. Iran J Biotech. 2013: 11(1):14-21. DOI: 10.5812/ijb.9305

* Corresponding author: Masoud Shams-Bakhsh, Department of Plant Pathology, Faculty of Agriculture, Tarbiat Modares University, Tehran, IR Iran. Tel: +982148292274, Fax:+98-2148292200, E-mail: shamsbakhsh@modares.ac.ir

DOI: 10.5812 /ijb.9305

Copyright (C) 2013, National Institute of Genetic Engineering and Biotechnology; Published by Kowsar Corp.

This is an Open Access article distributed under the terms of the Creative Commons Attribution License (http://creativecommons.org/licenses/by/3.0), which permits unrestricted use, distribution, and reproduction in any medium, provided the original work is properly cited. 


\section{Background}

The witches' broom disease of lime (WBDL) is a destructive disease caused by Candidatus Phytoplasma aurantifolia (1). It was first observed in Oman (2) then it was reported in the United Arab Emirates (3) and Iran (4). It is estimated that over $98 \%$ of lime trees in Oman are infected with WBDL (5). The lime trees infected with WBDL show different symptoms such as compactness and their very small, pale green leaves, stunting, yellowing and shortening of internodes. As the disease progresses, the leaves dry, many witches' brooms appear, and in four or five years the infected tree collapses. No flowers or fruits are produced in case of witches' brooms and the ones produced on normal shoots are reduced in size (5). Phytoplasmas are wall-less prokaryotes which belong to Mollicutes, and are known with their specific characteristics such as small genomic size from 530 to $1350 \mathrm{~kb}(6)$, low $\mathrm{G}+\mathrm{C}$ percent (7), nonculturable in cell free media (8), transmission and spread by insect vectors mainly leaf hoppers (Cicadellidae) and plant hoppers (Delphacidae), and multiplication in the phloem sieve tubes. They are phloem-limited bacterial pathogens which colonize their host persistently and cause great losses in economically important plants like ornamentals, vegetables and fruit trees (9). Phytoplasmas are surrounded by a single cell membrane. The membrane proteins of phytoplasmas appear to do their function directly in the cytoplasm of the host plant and transmitting insect cells (10). A subset of membrane proteins are in the phytoplasma cells, of which the immunodominant membrane proteins (IMPs) are the major part (11). The IMPs are located on the external surface of the cell membrane (12), and probably play important roles in the attachment to their host cell surface (13). Considering the rapid spread of the disease, a correct, precise and highly sensitive detection method is necessary for quick identification of infected samples and prevention of infected plant materials translocation. Several diagnostic techniques have been developed to detect phytoplasmas. Molecular methods such as polymerase chain reaction (PCR) (14), DNA hybridization (15) and electron microscopy (16) have been described. Each of these methods has inherent disadvantages. PCR and DNA hybridization require specialized equipment. In contrast, serological detection is convenient and economical method which allows examination of many samples in a short time. Up to now, several polyclonal and monoclonal antibodies have been produced against numerous phytoplasmas including clover phyllody (CP) (17), aster yellows (AY) (18), ash yellows (19), faba bean phyllody (20) and lime witches' broom (21). Considering the fact that phytoplasmas have not been cultured in vitro, such antibodies have been produced by purifying or partially purifying phytoplasma cells from infected plants. These antibodies have some disadvantages such as low titers, cross reactivity with plant components and weak specificity to the target phytoplasma. To overcome these difficulties, recombinant IMP has been successfully used to produce antibody against several phytoplasmas causing apple proliferation (AP) (22), Western X-disease (WX) (23) and onion yellows (OY) (13). Moreover, traditional approach to prepare antibody against phytoplasmas is based on immunizing animal with antigen preparations from infected plants. This approach results in antisera with relatively low titer, contamination with plant-derived immunogens and occurrence of cross reactions with healthy crude extracts (13). As it has been applied for several plant viruses $(24,25)$, the cloning and expression of the phytoplasma gene fragment in E. coli and purification of the protein are proposed as a means to advance our ability to overcome these limitations.

\section{Objectives}

This work aimed to describe the application of recombinant IMP to develop specific antibody against Candidatus Phytoplasma aurantifolia and produce a DAS-ELISA serological kit for efficient detection of infected plants.

\section{Materials and Methods}

\subsection{Materials}

All chemicals were supplied from the Fermentas (Vilnius, Lithuania), Qiagen (Hilden, Germany), Roche (Mannheim, Germany), Sigma (Deisenhofen, Germany) and Fluka (Neu-Ulm, Germany) Companies. The QIA expressionist and Ni-NTA agarose matrix (Qiagen, Hilden, Germany) were used for expression and purification of recombinant protein. Immobilon-P transfer membrane (PVDF) $(0.45 \mu \mathrm{m})$ was from Sigma (Deisenhofen, Germany). DNA Extraction Kit (Roche, Mannheim, Germany) and restriction enzymes, PCR materials and InsTAcloneTM PCR Cloning Kit were prepared from Fermentas (Vilnius, Lithuania). Synthetic oligonucleotides were obtained from MWG-Biotech (Ebersberg, Germany).

\subsection{Phytoplasma and DNA Extraction From the Infected Plants}

Phytoplasma was maintained by serial transmission from diseased to healthy plants using graft transmission in Citrus aurantifolia from a lime plant infected by WBDL (Kindly provided by Dr. Mohsen Mardi, ABRII, Karaj, Iran). These plants were used as the main source to isolate IMP and subsequent analysis. All healthy and diseased plants were grown in an insect-proof greenhouse. Stems and leaves of the WBDL infected lime plant were frozen with liquid nitrogen and ground to a fine powder. Total DNA was isolated and purified using Cetyltrimethylammonium bromide (CTAB) method (26).

\subsection{Isolating, Cloning and Sequencing of the IMP Gene}

The primer set IMP-pET28-For (5'-CAACGTCGACAAAATCACAAAGAAAATTTTTTAC-3`), and IMP-pET-28-Rev 
(5'-CAACGCGGCCGCTTATGATAATTTTAAATCTG-3) containing the restriction sites of the SalI and NotI enzymes. They were designed according to the IMP sequence (Accession No. GU339497.1) and were used to isolate the gene encoding IMP from infected plant. The PCR amplification was performed in a $50 \mu \mathrm{L}$ reaction volume containing 1 ng of extracted template DNA, $5 \mu \mathrm{L}$ PCR buffer (10×), 50 $\mathrm{mM} \mathrm{MgCl}_{2} 2.5 \mu \mathrm{L}, 2.5 \mathrm{mM}$ deoxynucleotide triphosphates $1 \mu \mathrm{L}, 10 \mathrm{pmol}$ of each primers (IMP-pET28-For and IMP-pET-

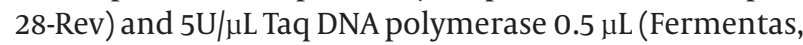
Vilnius, Lithuania). PCR was performed under the following conditions: initial denaturation at $94^{\circ} \mathrm{C}$ for $5 \mathrm{~min}$, followed by 35 cycles of denaturation at $94^{\circ} \mathrm{C}$ for $1 \mathrm{~min}$, annealing at $55^{\circ} \mathrm{C}$ for $1 \mathrm{~min}$ and extension at $72^{\circ} \mathrm{C}$ for $1.5 \mathrm{~min}$ and a final extension at $72^{\circ} \mathrm{C}$ for $12 \mathrm{~min}$. Amplification products were analyzed by electrophoresis on agarose gel $(1 \%)$, in $1 \times$ TAE buffer and stained with ethidium bromide $\left(0.5 \mu \mathrm{g} \cdot \mathrm{mL}^{-1}\right)$. Amplified fragments were recovered from gel using DNA Extraction Kit (Roche, Mannheim, Germany) and ligated into the plasmid vector pTZ57R/T (InsTAcloneTM PCR Cloning Kit, Fermentas, Vilnius, Lithuania). The recombinant plasmid was used for transformation of Escherichia coli strain $\mathrm{DH} 5 \alpha$ by heat-shock protocol (27). Intact clones containing right sequences were initially selected after digestion with SalI and NotI enzymes. To make sure that the amplification and construction processes have not affected the base sequence of IMP gene, the cloned gene was sequenced by Macrogen (Korea) using universal primers for pTZ57R/T.

\subsection{Heterologous Expression of the IMP Encoding Gene}

The clone containing the intact sequence of IMP was selected and the gene encoding IMP was subcloned into the SalI and NotI sites of pET28a bacterial expression vector and the new construct was designated pET28-IMP and transformed to E. coli strain BL21 (DE3). Expression of the IMP was induced under native conditions following the manufacturer's instructions (The QIA expressionist TM, Hilden, Germany) and purification was performed through Immobilized metal ion affinity chromatography (IMAC) in column containing Ni-NTA agarose beads (Qiagen, Hilden, Germany) following the manufacturer's instructions. For extracting soluble protein, cell disruption was performed by vortexing with glass beads and sonication (Misonix, USA). Successful expression and purification steps were confirmed by SDS-polyacrylamide gels (SDS-PAGE) (stacking gel 4\%, pH 6.8; separating gel $12 \%, \mathrm{pH} 8.8)(28)$.

\subsection{Antibody Preparation}

Two white inbred rabbits were used for immunization. Five intramuscular injections in the hind legs were performed at intervals of two weeks. Each injection contained about $100 \mu \mathrm{g}$ of IMP recombinant protein and equal volumes of complete Freund's adjuvant (Sigma, Deisenhofen, Germany) for the first injection and incom- plete Freund's adjuvant for the subsequent injections. Animals were bled 4 to 5 times from the marginal ear vein at 14 day intervals to estimate antibody titer by ELISA. Finally, blood was collected from rabbits' heart 14 days after the fifth immunization. The serum fraction was collected and stored at $-20^{\circ} \mathrm{C}$.

\subsection{Purification of $\operatorname{Ig} G$ and Conjugation With Alkaline Phosphatase}

Antibody purification from serum was performed using Protein A spin column according to the manufacturers' manual (AbDSerotec, UK). The concentration and the purity of antibody were determined by SDS-PAGE. Purified antibody was conjugated to alkaline phosphatase using LYNX Rapid alkaline phosphatase antibody conjugation kit based on the manufacturer's manual (AbDSerotec kit, UK).

\subsection{Western-Blot Analysis}

Purified IMP protein and the proteins extracted from the WBDL infected and healthy plants were separated by SDS-PAGE. Proteins were transferred to Millipore polyvinylidene difluoride (PVDF) membrane (Immobilon-P transfer membrane; Sigma Deisenhofen, Germany) according to the instructions of the manufacturer. The membrane was blocked with PBS buffer (137 mM NaCl, 2.7 $\mathrm{mM} \mathrm{KCl}, 8.1 \mathrm{mM} \mathrm{Na} \mathrm{HPO}_{4} \mathrm{X}_{2} \mathrm{H}_{2} \mathrm{O}, 1.5 \mathrm{mM} \mathrm{KH}_{2} \mathrm{PO}_{4}$; $\left.\mathrm{pH} 7.5\right)$ containing $2 \%(\mathrm{w} / \mathrm{v})$ skim milk powder and blotted proteins probed with a primary antibody (anti-His tag at a dilution of 1/1000 and anti-IMP polyclonal antibody at a dilution of 1/500). The alkaline phosphatase-conjugated secondary antibody was used at a dilution of 1/3000 (Abcam, USA). The target proteins were finally revealed by adding substrate 5-bromo-4-chloro-3-indolyl-phosphate (BCIP) and nitro blue tetrazolium (NBT) (Sigma, Deisenhofen, Germany).

\subsection{Enzyme linked Immunosorbent Assay (ELISA)}

Indirect ELISA was performed to determine the IMP polyclonal antibodies titer. A Nunc-Immuno ${ }^{\mathrm{TM}}$ MaxiSorb $^{\mathrm{TM}}$ 96-wells microtiter plate (Thermo Fisher Scientific Inc.) was initially coated with $10 \mu \mathrm{g} \cdot \mathrm{mL}^{-1}$ of purified recombinant IMP using a carbonate coating buffer $(15 \mathrm{mM}$ $\mathrm{Na}_{2} \mathrm{CO}_{3}, 35 \mathrm{mM} \mathrm{NaHCO}_{3} \mathrm{pH}$ 9.6) and plate was left overnight at $4^{\circ} \mathrm{C}$. The plate was blocked with $2 \%(\mathrm{w} / \mathrm{v})$ skim milk (Fluka, Neu-Ulm, Germany) in $1 \times$ PBS. Serial dilutions of serum (1/512-1/262144) in $1 \times$ PBS was added to the coated plate and incubated at $37^{\circ} \mathrm{C}$ for 2 hours. Bound antibodies were detected by adding 1/3000 diluted alkaline phosphatase-conjugated goat anti-rabbit IgG (Abcam, UK) for 2 hours at $37^{\circ} \mathrm{C}$. Finally, p-nitrophenyl phosphate (pNPP) as substrate (Sigma, Deisenhofen, Germany) was added and incubated at room temperature for 20 - $60 \mathrm{~min}$ followed by measuring the absorbance values at $405 \mathrm{~nm}$ using TECAN Microplate reader (Switzerland). To determine 
specificity of the prepared antibody against phytoplasmas, double antibody sandwich-ELISA (DAS-ELISA) was performed as described previously by Clark and Adams (29). Wells of the plate were coated with anti-IMP polyclonal antibody diluted to 1:500 in 1×PBS and incubated at $37^{\circ} \mathrm{C}$ for 2 hours. Extraction of plant material from healthy and infected lime were performed with mortar and pestle or in a plastic bag with a roller. Plant protein were extracted 1:3 (w/v) in extraction buffer $(1 \times \mathrm{PBS} \mathrm{pH} 7.5$, $5 \mathrm{mM}$ EDTA, $5 \mathrm{mM} \beta$-mercaptoethanol or $2 \%(\mathrm{v} / \mathrm{v})$ polyvinylpyrrolidone, molecular weight 10000 (PVP-10) in PBS). The plant extracts and purified protein control (IMP, positive control) were added to the plate and incubated overnight at $4^{\circ} \mathrm{C}$. Next, the alkaline-phosphatase-conjugated anti-IMP polyclonal antibody was added at a dilution of 1:500 and incubated at $37^{\circ} \mathrm{C}$ for 2 hours. Finally, the substrate (pNPP) was added and after 30 min absorbance values were read at $405 \mathrm{~nm}$. The sample was identified as positive if the mean DAS-ELISA (A405 nm) value of sample exceeded at least twice that of the healthy control(s).

\subsection{Dot Immunobinding Assay (DIBA)}

Protein extracts of healthy and infected lime plants were diluted 1:10, 1:20 and 1:50 in 1×PBS buffer and $4 \mu \mathrm{L}$ of each were disposed on nitrocellulose membrane. Saturation of the free binding sites was performed with $2 \%$ $(\mathrm{w} / \mathrm{v})$ skim milk in $1 \times$ PBS. The target protein was detected by 1:500 diluted AP-labeled anti-IMP IgG. The bound antibody was revealed by adding substrate NBT/BCIP.

\subsection{Specificity of the Anti-IMP Polyclonal Antibody}

Specificity of the polyclonal antibody prepared against recombinant IMP of lime witches' broom was evaluated with several phytoplasma-infected plant samples including almond infected with Candidatus Phytoplasma phoenicium (30), alfalfa infected with alfalfa witches, broom and sesame infected with a phytoplasma associated with sesame phyllody (31) using DAS-ELISA.

\section{Results}

\subsection{Detection and Cloning of the IMP Gene}

The gene encoding IMP was amplified using specific primers from total DNA extracted from the infected plant (Figure 1).

Sall/NotI Restriction sites were introduced into the forward and reverse primers for subcloning in to desired vectors. The PCR product was directly cloned into the pTZ57R/T vector and integrity of IMP gene in obtained clones was evaluated by restriction analysis, PCR amplification and sequencing. The clone harboring the right sequence was selected for subcloning in pET28a bacterial expression vector. Sequencing analysis revealed that the cloned DNA into pTZ57R/T vector consists of $519 \mathrm{bp}$, starting from the ATG initiation codon and stopping at
Figure 1. PCR Amplification of Immunodominant Membrane Protein Gene of Candidatus Phytoplasma Aurantifolia Using IMP-pET28-For and IMP-pET-28-Rev Primers

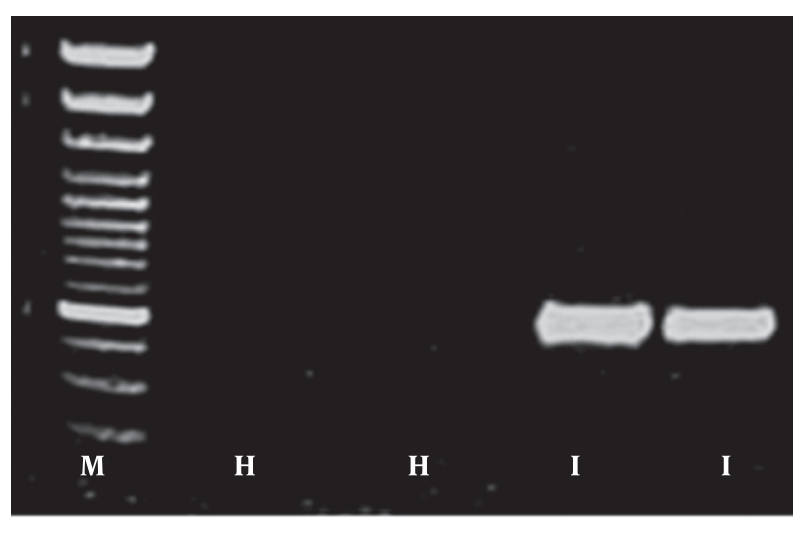

M, 10obp DNA ladder (Fermentas, Vilnius, Lithuania); H, healthy lime plants; I, lime witches' broom infected lime plants

translation termination codon of TAA and 100\% identity with IMP gene of Candidatus Phytoplasma aurantifolia (Table 1).

The multiple sequence alignment of the IMP with the sequences of the NCBI databases and ClustalW program indicated that this gene encodes a protein of 172aa which has the most similarity with membrane proteins of the members of Peanut WB group; faba bean phyllody, alfalfa witches' broom, peanut witches' broom (PNWB) and sweet potato witches' broom (SPWB) (Figure 2). Like the WX, AP, CP and SPWB IMPs, this gene contains no cysteine. All of the IMP genes isolated from phytoplasmas have a high lysine content ranging from $11.0 \mathrm{~mol} \%$ for $\mathrm{CP}$ to 14.6 mol\% in the AY IMP, and tryptophan (W) are encoded by TGG (23). This antigenic gene has twenty-seven AAA lysine codons (15.7 mol\%), which make it the most abundant amino acid and also two tryptophan residues are encoded by TGG.

\subsection{Expression of Recombinant IMP Protein}

To produce sufficient protein for immunization of rabbit and further characterization of prepared antibodies, the IMP gene was inserted into the pET28a bacterial expression vector downstream of a $6 \times$ His-tag and expressed in E. coli BL21 (DE3) under native conditions. The expressed IMP in bacteria cells was purified by purification of recombinant protein on Ni-NTA-agarose column. Disruption of bacterial cells using ultrasonic waves was more efficient than other approaches such as glass beads. Expression and purification resulted in the production of varying amounts of fusion protein after induction with $1 \mathrm{mM}$ IPTG. SDS-PAGE analysis confirmed the high purity and integrity of IMP and showed a protein with expected size of about $19 \mathrm{kDa}$ (Figure 3). Generally, the total yield of purified protein in the culture medium varied from 6 to $18 \mathrm{mg} \cdot \mathrm{L}^{-1}$. 


\begin{tabular}{|c|c|c|c|c|c|c|}
\hline Accession & Description & Max Score & Total Score & Query Coverage, \% & E Value & Max Identity \\
\hline GU339497.1 & $\begin{array}{l}\text { Lime witches'-broom phytoplasma } \\
\text { isolate LWB immunodominant mem- } \\
\text { brane protein gene, complete cds }\end{array}$ & 959 & 959 & 97 & 0.0 & $100 \%$ \\
\hline JQ745278.1 & $\begin{array}{l}\text { Faba bean phyllody phytoplasma } \\
\text { isolate FBP immunodominant mem- } \\
\text { brane protein gene, complete cds }\end{array}$ & 821 & 821 & 97 & 0.0 & $95 \%$ \\
\hline JQ745274.1 & $\begin{array}{l}\text { Alfalfa witches'-broom phytoplasma } \\
\text { isolate AlfWB-Y immunodominant } \\
\text { membrane protein gene, complete cds }\end{array}$ & 809 & 809 & 97 & 0.0 & $95 \%$ \\
\hline GU214176.1 & $\begin{array}{l}\text { Peanut witches'-broom phytoplasma } \\
\text { putative DNA replication initiation } \\
\text { protein (dnaD) and immunodomi- } \\
\text { nant membrane protein (imp) genes, } \\
\text { complete cds }\end{array}$ & 431 & 431 & 99 & 3e-117 & $82 \%$ \\
\hline U15224.1 & $\begin{array}{l}\text { Mycoplasma-like organism major } \\
\text { SPWB-MLO antigenic protein gene, } \\
\text { complete cds }\end{array}$ & 425 & 425 & 99 & 1e-115 & $81 \%$ \\
\hline
\end{tabular}

Figure 2. Protein Sequence Alignment of the WBDLIMP (ADC38921.1) Against Alf WB-Y (AFK64757.1), FBP (AFK64761.1), PNWB (ADD59806.1) and SPWB (AAC46382.1) Immunodominant Membrane Proteins With Clustal W Program

\begin{tabular}{|c|c|}
\hline WBDL & 1 MNHKENFLQTKNGKITVGVLASLGIAIVVYLIAAKLLHWKPFNITTLTNKDIENLKVDLKDLSGKQRVADLSSDDAKKEG 80 \\
\hline FBP & 1 MNHKENFLQTKNGKITVGVLASLGIAIVVYLIAAKLLHWKPFNITTLTNKDFENLKVDLKDLTGKQKASDLSSDDAKKEA 80 \\
\hline AlfWB-Y & 1 MNHKENFLQTKNGKITVGVLASLGIAIVVYLIAAKLLHWKPFNITTLTNKDFENLKVDLKDLTGKQKTSDLSSDDAKKEA 80 \\
\hline$P N W B$ & 1 MNHKENFLQTKNGKITVGVLASAGIALVVYLITAKLLHWAPFTIKTLTTKDIDNLKVEIKDFTGLNTKDKLSSDDAKQES 80 \\
\hline SPWB & 1 MNHKENFLQTKNGKITVGVLASAGIALVVYLITAKLLHWAPFTIKTLTTKDIDNLKVEIKDFTGLNTKDKLSSDDAKQES 80 \\
\hline$W B D L$ & 81 QKAVDGLKKIIDAFAENNKADDKDKKISSATMQSANDLKTKADDALKFVNEESAAPKEWNDADVVNFVNNKMVKASEIND 160 \\
\hline FBP & 81 QKAVDGLKKIIDAFTENNKADDKDKKISSATMQLANDLKTKADDALKFVNDESAASKGWDDADVVNFVNNKMVKTTDIDN 160 \\
\hline AlfWB-Y & 81 QKAVDGLKKIIDAFTENNKADDKDKKISSATMQLANDLKTKADDALKFVNDESAASKGWDDADVVNFVNNKMVKTTDIDN 160 \\
\hline$P N W B$ & 81 QKAFDAINKIVDAFAENNKADIKDKKISDSTIAAANNLKTKADNALKFVNENASVTNWTDDRVQDFVNNKVVKTKEIND 159 \\
\hline SPWB & 81 QKAFDAINKIVDAFAENNKADIKDKKISDSTIAAANNLKTKADNALKFVNENASVTNWTDDRVQDFVNNKVVKTKEIND 159 \\
\hline WBDL & 161 LLNKAKSDLKL-S 172 \\
\hline FBP & 161 LFTKAKSDLKL-S 172 \\
\hline AlfWB-Y & 161 LFTKAKSDLKL-S 172 \\
\hline$P N W B$ & 160 LLSQAKTDLKLqS 172 \\
\hline
\end{tabular}

\subsection{Immunization, Determination of Antibody Titer and Antibody Purification}

Recombinant IMP was used to immunize two rabbits. The antibody titer was determined by indirect ELISA and after the fifth boosting, the final polyclonal antibody titer was about 1:131072. The IgG was purified from serum and monitored for purity by SDS-PAGE which appeared as approximately $25 \mathrm{kDa}$ and $50 \mathrm{kDa}$ bands. Also the IgG concentration was quantified with comparison to known amount of a standard protein, BSA, which was calculated to be about $1 \mathrm{mg} \cdot \mathrm{mL}^{-1}$.

\subsection{Western Immunoblot Analysis}

Western blot analysis using anti $6 \times$ His tag monoclonal antibodies proved successful expression of IMP in E. coli cells (data not shown). Specificity of produced polyclonal antibodies against recombinant IMP was confirmed by western blotting analysis. A distinct band around $19 \mathrm{kDa}$ was detected in the purified protein (Figure 4).

Subsequent western blotting analysis proved specificity of polyclonal antibodies against IMP presented in infected plants (data not shown). Complementary DIBA analysis was performed to further evaluate the specificity 


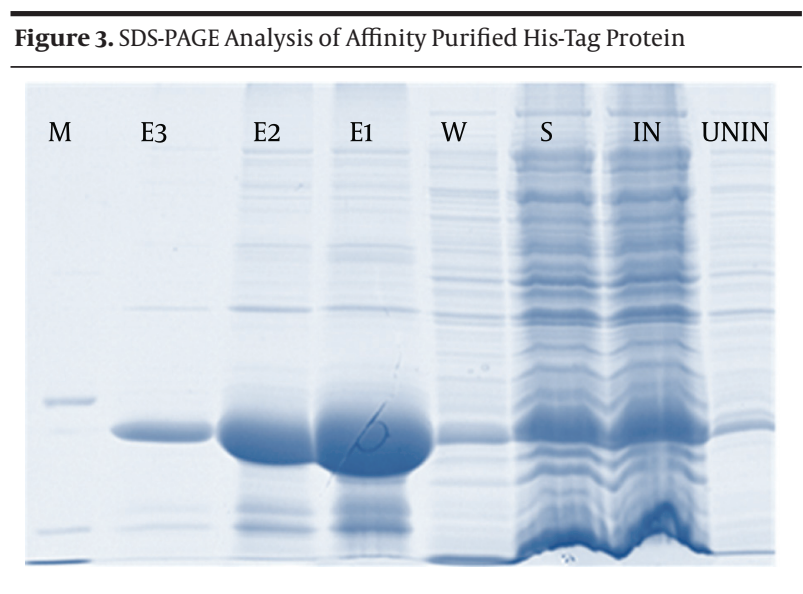

M, nonstained protein molecular weight marker SM0431 (Fermentas, Vilnius, Lithuania); E, elution fractions; W, washing stage; S, supernatant; IN, induced cells expressing Immunodominant membrane protein; UNIN, uninduced control

Figure 4. Western Blot Analysis of Purified Immunodominant Membran Protein with Alkaline Phosphatase -Conjugated Polyclonal Antibody at 1:500 Dilution

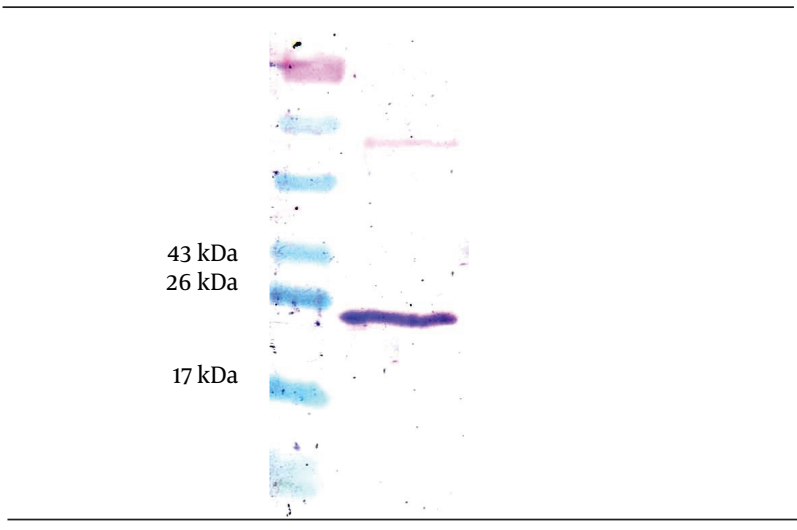

Abbreviations: M, prestained protein ladder SM0671, (Fermentas, Vilnius, Lithuania); IMP, Immunodominant Membrane Protein

Figure 5. Dot Immunobinding Assay Detection of the Lime Witches' Broom Phytoplasma with Alkaline Phosphatase -Conjugated Polyclonal Antibody at 1:500 Dilution

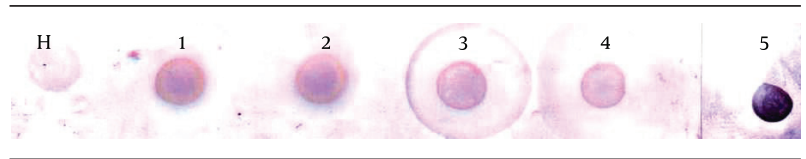

H, healthy lime plant; $1-4$, infected lime plants; 5 , purified Immunodominant membrane protein

of the prepared antibody against recombinant and native IMP. The results proved binding ability of antibody against IMP present in infected sap as well as against recombinant IMP (Figure 5).
Figure 6. Detection of Phytoplasma-Infected Plant Samples Using DAS-ELISA with Polyclonal Antibody Prepared Against Lime Witches' Broom (LWB) at a 1:500 Dilution as Presented by Absorbance Values of the Samples

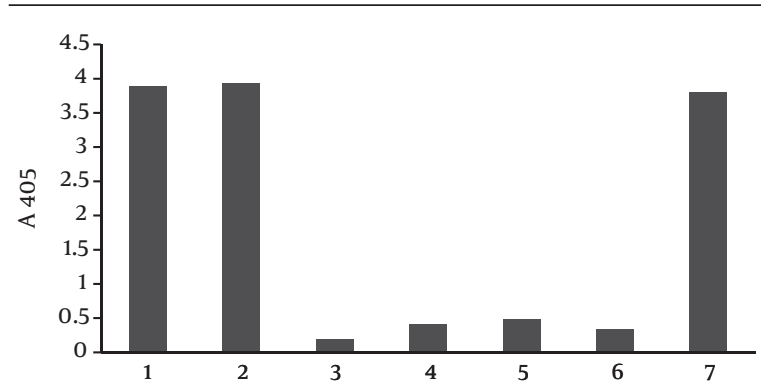

1, LWB-infected plant; 2, purified immunodominant membrane proteins; 3, healthy lime plant; 4 - 5, almond sample infected with Candidatus Phytoplasma phoenicium from Fars and Birjand, respectively; 6 , alfalfa sample infected with alfalfa witches', broom; 7, sesame sample infected with a phytoplasma associated with sesame phyllody.

\subsection{DAS-ELISA Technique}

To establish an effective method to detect the infected plant, DAS-ELISA analysis was performed. This technique required preparation of a scaffold for quantifying pathogen and making direct comparison between infected plants. Applying DAS-ELISA proved the ability of prepared antibodies for successful detection and differentiation of infected samples from the healthy ones at a dilution of 1:500 (Figure 6). Serial dilutions of prepared polyclonal antibody proved that the dilution of 1:2000 could be applied for further diagnostic purposes.

Each value represents the mean of 3 replicates. Absorbance values were read at $405 \mathrm{~nm}$ after $30 \mathrm{~min}$ of incubation. The differences among the groups and between each two groups were statistically significant $\mathrm{P}<0.05$ except for alfalfa plants infected by witches' broom. To determine binding activity of the prepared antibody against other phytoplasma agents, the DAS-ELISA analysis was performed using plants infected with witches' broom diseases of almond, alfalfa and sesame phyllody. The results revealed cross reactivity of prepared antibody with phytoplasmas present in almond and sesame, but no reaction was observed with infected alfalfa plants by witches' broom disease (Figure 6).

\section{Discussion}

The generation of specific antibodies against obligate parasites is greatly complicated due to the problems associated with obtaining pure material for immunization. Toward this aim and for efficient and simple detection of infected plants, present study described both production of specific antibodies against WBDL using recombinant IMP and development of serological methods such as DAS-ELISA and DIBA. A single major antigenic protein with a molecular mass ranging from 15 to $32 \mathrm{kDa}$ has been 
identified in several phytoplasmas $(3,13,22,23,32-36)$. Proteins from different strains usually have great amino acid and antigenic variation. All of the proteins have a central hydrophilic region, which may be on the outside of the phytoplasma cell, and one or two transmembrane domains. In this study, a protein with a molecular mass of about $19 \mathrm{kDa}$ and a pI value of 9.29 was detected. This protein showed similarities to an antigenic membrane protein of the sweet potato witches' broom (SPWB) agent described by Yu et al. (37). The multiple sequence alignment showed that the $\mathrm{NH}_{2}$-terminal amino acids of 1 to 20 are fully conserved between the N-termini of FBP, Alf WB-Y, PNWB, SPWB, and WBDL. In previous studies two distinct regions, a strongly hydrophobic $\mathrm{NH}_{2}$-terminus (amino acids 10 - 50) and a highly hydrophilic $\mathrm{C}$ terminus (amino acids 50 - 172), have been identified in the hydrophobicity profile of the deduced amino acid sequence of the major antigenic protein of SPWB phytoplasma (37). Regarding 70\% amino acid sequence identity between the major antigenic protein of SPWB phytoplasma and WBDL, a strongly hydrophobic $\mathrm{NH} 2$-terminus within the cell membrane (aa 1 - 14), a highly hydrophilic C-terminus exposed at the cell surface (aa 38 -172) and also a transmembrane protein (aa 15 - 37) were predicted for IMP of WBDL. The obtained purified protein was used for the immunization of rabbit and preparation of a polyclonal antibody against the lime witches' broom disease. The alkaline phosphatase labeled antibody was used in DAS-ELISA test and it detected the pathogen and exhibited a high specificity. Although DIBA test revealed a lesser sensitivity in comparison with DAS-ELISA, yet a smaller amount of antigen is required and detection of a large number of plants under field conditions would be rapid and easy. Considering the fact that phytoplasma infected sesame and almond plants react positively with anti-IMP polyclonal antibody, it can be concluded that there are serological associations between these phytoplasmas and phytoplasma associated with the LWB disease. Both polyclonal and monoclonal antibodies have been generated against phytoplasmas for their detection and differentiation. The relative sensitivities of polyclonal antibodies produced against several phytoplasmas such as: aster yellows, peanut witches' broom, phytoplasma associated with faba bean, sesamum phyllody, apple proliferation and sandal spike phytoplasma were determined using indirect ELISA procedure $(20,22,38,39)$. Polyclonal antibodies can be provided rapidly, at less expense, with less technical skill than required to produce monoclonal antibodies but it has mainly the disadvantage of cross reactivity with related antigens and limited products obtained in this way. Recombinant DNA and molecular display technologies have provided new opportunities to create recombinant antibodies. Phage display, involves the introduction of peptide sequences (such as the antigen-binding domains of recombinant antibodies) into the coat protein gene of a bacteriophage displayed on the virion surface. Phage antibody display libraries can be screened and the corresponding antibody gene can then be recovered from the phage genome (40). This technique is simple, cheap, and rapid and requires no special equipment. "The ethical and financial burdens of animal use are avoided because of the exclusion of immunization" (41). It has been shown that immunoassays are more reliable and sensitive in detecting the phytoplasmas in their host and for establishing relationships among phytoplasmas (33). The purity of the immunogen has significant effect on the sensitivity and specificity of immunoassays. As phytoplasmas cannot be cultured on cell free media, therefore, obtaining recombinant proteins which are very highly purified immunogen and produce good quality antisera when injected into rabbits is recommended. The antibody generated against IMP can be used for detection of procedures and also for other purposes like the characterization of secretion pathways or the study of host-pathogen interaction. In conclusion, witches' broom disease of lime has become the most important disease of lime in south of Iran during the last two decades, and there was no efficient strategy to control the disease. To restrict the spread of the infected plant materials, for quarantine purposes, eradication programs and resistance breeding trials, sensitive and specific detection tools were needed. Antibodies against IMP of Candidatus Phytoplasma aurantifolia have been proven to be very powerful tools to detect the pathogen.

\section{Acknowledgements}

We would like to thank Dr. M. Ghaeb-Zamharir and SA Esmailzadeh-Hosseini for providing infected samples and Dr. G. Hosseini Salekdeh and Mr. H. Rassol for their valuable cooperation in conducting the protein purification experiment.

\section{Authors' Contribution}

None declared.

\section{Financial Disclosure}

None declared.

\section{Funding/Support}

Financial support of the national project of WBDL and Agriculture Biotechnology Research Institute of Iran (ABRII) is acknowledged.

\section{References}

1. Zreik L, Carle P, Bove JM, Garnier M. Characterization of the mycoplasmalike organism associated with witches'-broom disease of lime and proposition of a Candidatus taxon for the organism, "Candidatus phytoplasma aurantifolia". Int J Syst Bacteriol. 1995;45(3):449-53.

2. Bove JM. Witches' broom disease of lime. FAO Plant Protec Bulletin. 1986;34(4):217-18 
3. Garnier M, Zreik L, Bové JM. Witches' broom, a letha mycoplasmal disease of lime in the Sultanate of Oman and the United Arab Emirates. Plant Dis. 1991;75(6):546-51.

4. Bove JM, Danet JL, Banane JK, Hassanzadeh N, Taghizadeh M, Salehi M, et al. Witches' broom disease of lime in Iran. Fourteenth IOCV Conference; 2000; Iran. 2000. p. 207-12.

5. Chung KR, Khan IA, Brlansky RH. Citrus Diseases Exotic to Florida: Witches' Broom Disease of Lime (WBDL). Florida: IFAS Extentention; 2006

6. Marcone C, Neimark H, Ragozzino A, Lauer U, Seemuller E. Chromosome sizes of phytoplasmas composing major phylogenetic groups and subgroups. Phytopathology. 1999;89(9):805-10.

7. Weisburg WG, Tully JG, Rose DL, Petzel JP, Oyaizu H, Yang D, et al. A phylogenetic analysis of the mycoplasmas: basis for their classification. J Bacteriol.1989;171(12):6455-67.

8. Lee IM, Gundersen-Rindal DE, Bertaccini A. Phytoplasma: ecology and genomic diversity. Phytopathology. 1998;88(12):1359-66.

9. Lee IM, Davis RE, Gundersen-Rindal DE. Phytoplasma: phytopathogenic mollicutes. Annu Rev Microbiol. 2000;54:221-55.

10. Hogenhout SA, Oshima K, Ammar el D, Kakizawa S, Kingdom HN Namba S. Phytoplasmas: bacteria that manipulate plants and insects. Mol Plant Pathol. 2008;9(4):403-23.

11. Shen WC, Lin CP. Production of monoclonal-antibodies against a mycoplasmalike organism associated with sweet-potato witches-broom. Phytopathology. 1993;83:671-5.

12. Milne RG, Ramasso E, Lenzi R, Masenga V, Sarindu N, Clark MF. Pre- and post-embedding immunogold labeling and electron microscopy in plant host tissues of three antigenically unrelated MLOs: primula yellows, tomato big bud and bermudagrass white leaf. Europ JPlant Pathol.1995;101(1):57-67.

13. Kakizawa S, Oshima K, Nishigawa H, Jung HY, Wei W, Suzuki S, et al. Secretion of immunodominant membrane protein from onion yellows phytoplasma through the Sec protein-translocation system in Escherichia coli. Microbiology. 2004;150(Pt 1):135-42.

14. Namba S, Kato S, Iwanami S, Oyaizu H, Shiozawa S, Tsuchizaki T. Detection and differentiation of plant-pathogenic mycoplasma like organisms using polymerase chain reaction. Phytopathology. 1993;83:786-91.

15. Kirkpatrick BC, Stenger DC, Morris TJ, Purcell AH. Cloning and Detection of DNA from a Nonculturable Plant Pathogenic Mycoplasma-like Organism. Science. 1987;238(4824):197-200.

16. Doi Y, Teranaka M, Yora K, Asuyama H. Mycoplasma- or PLT Grouplike Microorganisms Found in the Phloem Elements of Plants Infected with Mulberry Dwarf, Potato Witches' Broom, Aster Yellows, or Paulownia Witches' Broom. Japanese J Phytopathol. 1967;33(4):259-66.

17. Sinha RC. Purification of mycoplasma-like organisms from China aster plants affected with clover phyllody. Phytopathology. 1974;64:1156-8.

18. Errampalli D, Fletcher J, Sherwood JL. Production of specific polyclonal antibodies against the aster yellows mycoplasma-like organisms (AY MLO) of Oklahoma. Phytopathology. 1989;79:1137.

19. Chen TA, Jiang YP. Progress in the detection of plant mycoplasma-like organisms by using monoclonal and polyclonal antibodies. Zentralbl Bakteriol Suppl. 1990;20:270-75.

20. Saeed EM, Roux J, Cousin M. Studies of polyclonal antibodies for the detection of MLOs associated with faba bean (Vicia faba L.) using different ELISA methods and dot-blot. J Phytopathol. 1993;37:33-43.

21. Mirzai M, Heydarnejad J, Salehi M, Hosseinipour A, Massumi $\mathrm{H}$, Shaabanian M. Production of polyclonal antiserum against the causal agent of lime witches' broom. Iran J Plant Pathol. 2009;45(2):155-9.

22. Berg M, Davies DL, Clark MF, Vetten HJ, Maier G, Marcone C, et al. Isolation of the gene encoding an immunodominant membrane protein of the apple proliferation phytoplasma, and expression and characterization of the gene product. Microbiology. 1999;145(Pt 8):1937-43.

23. Blomquist CL, Barbara DJ, Davies DL, Clark MF, Kirkpatrick BC. An immunodominant membrane protein gene from the Western $\mathrm{X}$-disease phytoplasma is distinct from those of other phytoplasmas. Microbiology. 2001;147(Pt 3):571-80.

24. Shams-Bakhsh M, Symons RH. Cloning and expression of the coat protein gene of barley yellow dwarf virus-PAV in Escherichia coli. Iran J Biotech. 2004;2(2):84-9.

25. Cerovska N, Moravec T, Plchova H, Hoffmeisterova H, Folwarczna $\mathrm{J}$. Production of polyclonal antibodies to potato virus $\mathrm{X}$ using recombinant coat protein. J Phytopathol. 2010;158:66-8.

26. Zhang Y-p, Uyemoto JK, Kirkpatrick BC. A small-scale procedure for extracting nucleic acids from woody plants infected with various phytopathogens for PCR assay. J Virolog Meth. 1998;71(1):4550.

27. Sambrook J, Fritsch EF, Maniatis T. Molecular cloning: A laboratory manual. New York: Cold Spring Harbor Press; 1989.

28. Ausubel FM, Brent R, Kingston RE, Moore DD, Seidman JG, Struhl K. Current Protocols in Molecular Biology. John Wiley \& Sons; 1988.

29. Clark MF, Adams AN. Characteristics of the microplate method of enzyme-linked immunosorbent assay for the detection of plant viruses. J Gen Virol. 1977;34(3):475-83.

30. Salehi M, Izadpanah K, Heydarnejad J-. Characterization of a new almond witches'broom phytoplasma from Iran. J Phytopathol. 2006;154(7-8):386-91.

31. Esmailzadeh-Hosseini SA, Mirzaie A, Jafari-Nodooshan A, Rahimian $\mathrm{H}$. The first report of transmission of a phytoplasma associated with sesame phyllody by Orosius albicinctus in Iran. Aus Plant Dis Notes. 2007; 2:33-4.

32. Jiang YP, Lei JD, Chen TA. Purification of aster yellows agent from diseased lettuce using affinity chromatography. Phytopathology. 1988;78:828-31.

33. Clark MF, Morton A, Buss SL. Preparation of mycoplasma immunogens from plants and a comparison of polyclonal and monoclonal antibodies made against primula yellows MLO-associated antigens. Ann Appl Biol. 1989;114(1):111-24.

34. Saeed E, Rage P, Cousin MT. Determination of the antigenic protein size associated with faba bean phyllody MLO by using (SDS- PAGE) electrophoresis and immunotransfer.J Phytopathol. 1992;136:1-8.

35. Seddas A, Meignoz R, Daire X, Boudon-Padieu E, Caudwell A. Purification of grapevine flavescence dorée MLO (Mycoplasma-like organism) by immunoaffinity. Curr Microbiol. 1993;27(4):229-36.

36. Chang F, Chen CC, Lin CP. Monoclonal antibody for the detection and identification of a phytoplasma associated with rice yellow dwarf. Europ J Plant Pathol. 1995;101(5):511-8.

37. Yu YL, Yeh KW, Lin CP. An antigenic protein gene of a phytoplasma associated with sweet potato witches' broom. Microbiology. 1998;144(Pt 5):1257-62.

38. Lin CP, Chen TA. Comparison of monoclonal antibodies and polyclonal antibodies in detection of aster yellows mycoplasma-like organism. Phytopathology. 1986;76:45-50.

39. Thomas S, Balasundaran M. Purification of sandal spike phytoplasma for the production of polyclonal antibody. Curr Science Online. 2001;80(12):1489-94.

40. Safarnejad MR, Jouzani GS, Tabatabaei M, Twyman RM, Schillberg S. Antibody-mediated resistance against plant pathogens. Biotechnol Adv. 2011;29(6):961-71.

41. Willats WG. Phage display: practicalities and prospects. Plant Mol Biol. 2002;50(6):837-54 